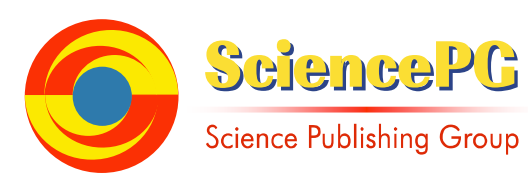

\title{
Access to Housing Finance by the Poor and Study of Microfinance for Housing (MFH) in India
}

\author{
Basanta K Sahu \\ Dept. of Economics, Indian Institute of Foreign Trade, New Delhi, India
}

Email address:

bksgps@gmail.com

To cite this article:

Basanta K Sahu. Access to Housing Finance the Poor and Study of Microfinance for Housing (MFH) in India. International Journal of Business and Economics Research. Vol. 4, No. 6, 2015, pp. 270-280. doi: 10.11648/j.ijber.20150406.12

\begin{abstract}
Access to housing finance is a major challenge for the poor and low income groups because of underdeveloped housing finance market, high transaction cost, lack of collateral, type of housing credit and other factors specific to local area. The paper analyzes nature and pattern of microfinance for housing (MFH) in India and its impact on low segment housing finance. Using primary data collected from microcredit clients from different regions in two southern states in India (Kerala and Karnataka) it discusses two different MFH schemes to understand low segment housing finance and its impact on rural housing activities. Our data support to estimate the approximate size of the low segment housing credit market and the existing gap between demand for and supply of such credit. Findings of the paper offer better understanding about functioning of low segment housing finance markets and potential to improve housing condition of the poor through developing such markets including MFH. Major constraints of MFH program in India are inadequate fund, poor product design, low scale of operation scale and policy related issue. Inter-links between microcredit and MFH is evident from our data. Average demand for housing credit was estimated three times higher than its supply and mostly for new construction of houses rather to repair and renovate existing houses. Though MFH found inadequate to meet the demand for housing credit but it works as kick starts for housing activities and influences household decision making in terms of start of housing activities, fund arrangement and utilization, allocation of resources, asset creation etc. which are crucial for the poor. Housing activities in our study not found progressive as argued by earlier study [1].
\end{abstract}

Keywords: Access to Housing Finance, Microfinance for Housing (MFH), India

\section{Introduction}

Safe and affordable housing is one of the basic human needs and the single most important factor creating conditions of decent living, employment, incomes and asset creation, particularly for the poor and low income groups. On the other hand homelessness often led to gradual process of low productivity and deprivation and result in adverse socioeconomic-health consequences. World-wide there is huge shortage of housing [2]. Though provision of 'housing for all' has been re-emerged as a development policy across countries, the gap between demand and supply of low cost housing is alarming in many developing countries. Efforts of pro-poor housing policies seem fail in reducing the housing shortage and improve living standard of the poor and homeless. Though pro-poor housing and housing finance have taken center stage in many policy debates and policy formulation but the challenge of housing shortage continues.
The housing situation in India, the second most populous country in the world, is precarious. 'Rahneko ghaar nehein par saree Hindustan haamara' - No house to stay but the Entire India is mine'. Though the national housing policy reemphasizes provision of shelter for attainment of better health, hygiene, education that stimulate economic activity, enhance productivity, motivate savings and promote social justice, unacceptable housing condition for poor and growing scarcity of low cost housing in India is evident ${ }^{1}$. Shortfall of houses estimated in India is about 27 million units in urban areas and 43 million units in rural areas, out of which more than 90 percent housing shortage is in low income groups [3]. Over 170 million people live in slums without adequate

\footnotetext{
1 The $11^{\text {th }}$ Five Year Plan estimates the urban housing shortage at the commencement of Plan period was 24.7 million units, with $99 \%$ of this shortage pertaining to the economically weaker sections (EWS) and lower income groups (LIG). The situation is further aggravated by high shortage of rural housing about 7 million (RBI, 2009).
} 
access to clean water, sanitation and security of tenure, and another two million are homeless [4]. So making housing for the poor has drawn attention of the policy makers and others keeping in mind the multiple effects - generation of income, accumulation of asset and enhancing creditworthiness and better resources use. Admittedly, priority for housing found higher than for education and health among low income and weaker groups [5]. But investing in housing, both public and private, remain challenging and has not been affordable, easy and smooth due to several factors - it requires larger fund, cleaned land and other arrangements without immediate return. Housing finance is often said to the key factor for homelessness but the issues at regional and group level could be different and more complex.

Studies show that low budget housing finance demand and supply targeting low-income groups has traditionally been excluded from the mainstream housing market due to problem of land title and high investment requirements [6]. Given the credit market constraints for the poor, the problem of low segment housing sector is further compounded by growing urbanization, fragmentation and sub-division of land, ill-defined land ownership, collateral for mortgage finance and other factors. Public housing policy interventions are also suffered from effectiveness, transparency and delivery related issues. For instance, major problems of pro-poor public housing programme in India, are

1) lack transparency and efficiency that exclude the poor and needy beneficiaries

2) many public housing schemes are initiated without basic infrastructure and need.

3) housing technology, design, construction materials, etc. are not always match to the local conditions.

4) houses under public programme have high recurring costs.

5) constraints of land and finance for housing.

In sum, inability of the state to provide adequate housing to the poor and access to affordable housing finance by the bottom of the pyramid (BOP) pose serious threat to meet the goal of housing for all. As discussed in the development literature, the poor have multiple credit constraints in general and arranging credit for housing activity in particular. It becomes more challenging because of the nature and quantum of housing credit at the initial stage. Therefore, low segment housing sector continues to be over constrained by access to adequate and affordable credit and conventional housing finance markets fail to cater to the poor. In this context, to address the 'real housing problem' in the country it is imperative that alternative models for housing finance, like microfinance in housing or housing microfinance (HMF). Development of housing microfinance by applying microfinance practices could be much needed services to many house-poor families. Though HMF has been a quite successful tool in many parts of the world for addressing the housing problem of the poor and the marginalized, the same is yet to pick up considerable momentum in India. Even much is not known about nature, pattern and impacts microfinance for housing (MFH) in regional and group perspective. The present paper attempts to analyze issues relating microfinance for housing in India, where rising homelessness coexist with increasing growth of formal housing finance.

\section{Microfinance for Housing (MFH)}

Microfinance institutions have long observed that microcredit clients use a sizeable part of part of microenterprise loan for improvement of their living conditions [4]. They borrow for income generation activities but often channel the funds, partially or fully, into housing improvements. Since micro-enterprise loan offers much better repayment terms than informal sources of money lending, such loans can serve as a supplement towards housing improvements. Based on these experiences, some MFIs extend microcredit for asset creation, housing activities etc. as many active clients can finance their habitat needs in a manner that is incremental and affordable. Similarly, other formal credit lending institutions like commercial banks and regional banks (RRBs) broadened and diversify their lending portfolios to offer housing finance products under pro-poor public housing schemes. Although the microfinance sector has expanded exponentially in India, growth of housing microfinance remains limited due to lack of dedicated capital and limited capacity of microfinance institutions (MFIs). However, some trend of MFH has been observed in some southern regions where performance of microcredit program is much better it has been also initiated in other parts of India (UP, WB, Odisha). Some NGO (SEWA in Gujarat) has already following its own $\mathrm{MFH}$, designed to meet the housing needs of its clients who have been excluded from formal mortgage loans. A recent study by Centre for Innovation in Shelter and Finance [6] found that there is huge demand for MHF in southern region - Tamil Nadu, where clients often want a higher loan amount irrespective of the needs and affordability. With high demand for housing finance there was an interest in housing support services.

MFH is a non-subsidized, sustainable approach tailored to the needs of the low-income market. Within need for housing credit may vary subject housing activities like new construction, repair and maintenance, expansion etc. in incremental steps, relying on sequential small loans. With substantial growth and outreach of microcredit, it is obvious the requirement of housing credit by their clients. But many lending institutions including MFIs have not adequately responded to their clients demand for housing [7]. On the other hand, many microcredit lending institutions are keen to diversify their portfolios into housing credit and to remain competitive in the market [8] [9]. So there is huge supply potential for MFH but studies on MFH in India are few and limited.

On the demand side, household's decision to invest in housing is influenced by rising level of income in recent years [10]. Three basic arguments for low segment housing credit demand are. First, housing is a basic need, necessary for safety, health and dignity. Second, housing as an asset and 
investment in housing is a significant gauge of social and economic status for a poor person. Third, housing is an investment for income generating activities. Home improvements provide the opportunity for higher productivity and thus, higher income. Our focus in the study is on household's decision on demand for housing and housing credit as given below.

a) Housing for family and livestock: provision of living space for family members and livestock

b) Housing priority: improving safety, health and sanitary conditions such as bathrooms, toilet, strengthening wall, roof and entrance

c) Asset creation: housing as a valuable assets

d) Status: equating or upgrading social and economic identity or status

e) Income generation: investment for home based income generation activities.

f) Progressive/incremental nature: nature of housing activities and its uses.

Given the supply-side constraints - loan products, collateral, land ownership, legal aspects, transaction cost etc. that could limit housing priority and activity of many poor households we would like to examine the nature and pattern of housing activities among microcredit clients. Our aim is to capture the low segment housing sector in India where, the mortgage finance does not cater to the poor and low income groups because of their less ability to afford the debt service required. Then it becomes harder for the poor to build a house by arranging own fund.

It would be interesting to analyze the nature and pattern of low segment housing credit and housing activities particularly the incremental housing among the poor, as argued in earlier studies. It is equally important to understand the present housing condition, nature and pattern of housing plan and activities undertaken, source of housing finance and other related issues.

\section{Objectives, Methodology and Data}

Major objective of the paper is to analyze how MFH has influenced low segment housing activities and access to housing finance by the poor in the rural areas. We presume that wider outreach of micro-credit programme may help penetration of $\mathrm{MFH}$, arranging fund for housing and improve s housing finance condition among the poor.

Specific Objectives:

a) To analyze the demand of housing credit among low income groups, their priority of low segment housing activities and the existing gap at household level.

b) To assess functioning and impact of MFH on household decision on housing activities, fund management and it use for the same.

c) To discuss the potential of low segment housing credit market and role of MFH.

Our study is based on two housing microfinance programmes in India, selected on basis of their models, operation, product design and other aspects that match to meet the objectives. One MFH model is designed and supported by a public sector commercial banks and execute through the local community level body called Community Development Society (CDS) and the name of the MFH program is Bhwanshree in Kerala. The second model is a MFI sponsored MFH called Sanghamitra Rural Financial Services (SRFS) in Karnataka. Both models follow community and self-help group (SGP) approach to operate but have different in product design, execution, quantum and condition of credit. Selection of the study areas (state, districts and Taluks) was based on the incidence and intensity of the MFH programme. Selection of sample households, (most of them are microcredit clients) was made on representative random sampling to capture group and regional aspects relating to housing and other issues. Through field survey primary information were collected at household level with help of structured questionnaire, specially designed for the study. Total 110 households from four districts, two each from Kerala and Karnataka were interviewed followed by group wise focus group discussion (FGD) and collecting other information from local key informants. Collection of primary data includes information about housing conditions, quantum and nature of housing expenditure, current housing plan and activity, demand and sources of housing credit, loan repayment, microcredit group activities and major constraints and suggestion relating to housing finance.

\section{Housing Priority and Housing Finance in Study Areas}

Wish to have own house is one of the most important human entitlements, particularly among the poor and low income groups who spend a sizeable portion of their income on housing on regular basis. But cost of housing, both of having a house and not having it, could be multiple and not affordable to many. At household level cost of housing occurs not only in terms of meeting adequate housing for all family members, for storage and livestock etc. but also in terms of recurring cost of house maintenance and repair, house rent and other expenses. These costs largely depend upon the nature and type of house under use. Just to have brief idea about current housing condition in the study areas we try to assess the nature and type of existing housing condition, housing priority and plan, ongoing housing activities etc. and compare with their demand and supply of housing finance. From our primary survey two different scenarios emerges that provide some broad idea about low segment housing sector as a whole. The current housing condition of sample household is mostly inherited and it matches to their socio-economic and living conditions. To large extent it reflect their family size, asset holding, occupation, income, borrowing, saving, employment pattern and other socio-economic characteristics. These variables also directly or indirectly influence their housing priority and housing activities which further transformed into 
demand for housing finance.

Inadequate housing, both in terms of space and quality, found exist in the study areas and across the groups and regions but at different intensity. Though exact measurement of housing need was difficult due to relative measures and subjective approach of the respondents, due care was taken to net out individual perceptions of each sample households to reflect the nature and degree of housing inadequacy in the study areas. It may be seen from table - 1 that housing shortage is not only very high but has different other dimensions. More than 70 percent of total sample household reported their current housing less than the minimum required and about one-third viewed that housing shortage is acute and not manageable. It shows the high intensity of housing shortage among the low-income households who often confront with several hardships - food insecurity, poor health and hygienic, unsecure living and other problems. Under this situation, managing housing as basic need for living is a priority for at household and national level. However, the objective of income generation from additional housing as often argued, looks secondary or remote.

Table 1. Housing Conditions in Study Areas (in \% of HH).

\begin{tabular}{|c|c|c|c|}
\hline & Karnataka & Kerala & Total \\
\hline Bed Room & 71.7 & 45.8 & 58.0 \\
\hline Inadequate but Manageable & 71.1 & 66.7 & 69.2 \\
\hline Not Manageable & 28.9 & 33.3 & 30.8 \\
\hline Dining Space & 17.0 & 13.6 & 15.2 \\
\hline Inadequate but Manageable & 66.7 & 100.0 & 82.4 \\
\hline Not Manageable & 33.3 & 0.0 & 17.6 \\
\hline Kitchen & 71.7 & 20.3 & 44.6 \\
\hline Inadequate but Manageable & 73.7 & 75.0 & 74.0 \\
\hline Not Manageable & 26.3 & 25.0 & 26.0 \\
\hline Common used area & 71.7 & 6.8 & 37.5 \\
\hline Inadequate but Manageable & 78.9 & 50.0 & 76.2 \\
\hline Not Manageable & 21.1 & 50.0 & 23.8 \\
\hline Bathroom & 58.5 & 18.6 & 37.5 \\
\hline Inadequate but Manageable & 80.6 & 36.4 & 69.0 \\
\hline Not Manageable & 19.4 & 63.6 & 31.0 \\
\hline Toilet & 41.5 & 15.3 & 27.7 \\
\hline Inadequate but Manageable & 77.3 & 44.4 & 67.7 \\
\hline Not Manageable & 22.7 & 55.6 & 32.3 \\
\hline Livestock Shed & 87.5 & 0 & 70 \\
\hline Inadequate but Manageable & 87.5 & 0 & 70 \\
\hline Not Manageable & 12.5 & 100.0 & 30.0 \\
\hline Space for Economic Activity & 9.4 & 3.4 & 6.3 \\
\hline Inadequate but Manageable & - & - & \\
\hline Not Manageable & - & - & \\
\hline Over All Housing Inadequacy & 79.5 & 59.1 & 71.8 \\
\hline Inadequate but Manageable & 66.5 & 66.4 & 66.4 \\
\hline Not Manageable & 33.5 & 33.6 & 33.6 \\
\hline
\end{tabular}

Note: Figures in Bold show \% of $\mathrm{HH}$ having housing inadequacy in respective categories.

Figure without bold shows the degree of housing inadequacy in respective categories

Source: Field Survey

Regarding the type and nature of housing shortfalls, it was found prominent in the categories of bedroom, kitchen, bathroom and toilet and common use area. These are basic requirements for a family but the situation was worse in Karnatak than Kerala, where housing is given more importance due to different socio-economic practices. However, inability to manage with current housing shortage in Kerala is also evident. Sharp regional differences in terms shortage of specific housing needs, for instance, bath room, toilet, kitchen etc. found pronounced which has further implication on gender. The data presented in the table -1 also highlight how housing shortages were differently managed or not in the study areas. Interestingly, the alarming housing situations in the study areas found more or less similar irrespective of the level of income, occupation and other household features. It would be useful to analyze whether this trend could influence the household demand and priority of housing and housing finance.

Housing Priority in Study Areas:

Household's housing priority would determine the demand for housing finance which may vary subject to current housing need, existing housing condition, family's income flows, occupation, savings, borrowing and fund arrangement etc. The data presented in the table - 2 highlight some notable trends about housing priority and ongoing housing activities in the study areas. More than half of the sample household had priority for new house construction for which they were looking for credit. It shows the precarious current housing condition as well as high housing priority of the respondents that prompt for new house construction to meet their immediate need even though new house construction will be tough for them. Low priority for other housing activities like repairing, additional house, strengthening roof and wall etc. found in the study areas shows that few households have house that can be repaired or renovated for further use. In contrast to general understand, household priority for housing and housing credit in the study areas was to meet immediate self-living rather using housing for any income generating activity. However, after meeting immediate housing need any further demand for housing may induce for home based income generating enterprise, which found abysmally low in the study areas.

Table 2. Demand \& Priority for Housing in Study Areas (Borrowing Households).

\begin{tabular}{|c|c|c|c|c|c|c|}
\hline & \multicolumn{2}{|c|}{ Karnataka } & \multicolumn{2}{|l|}{ Kerala } & \multicolumn{2}{|l|}{ Total } \\
\hline $\begin{array}{l}\text { Housing } \\
\text { Activities }\end{array}$ & $\begin{array}{l}\mathrm{HH} \\
\text { (Nos) }\end{array}$ & $\%$ & $\begin{array}{l}\mathrm{HH} \\
\text { (Nos) }\end{array}$ & $\begin{array}{l}\mathrm{HH} \\
(\%)\end{array}$ & $\begin{array}{l}\mathrm{HH} \\
(\mathrm{Nos})\end{array}$ & $\%$ \\
\hline New construction & 27 & 50.9 & 40 & 70.2 & 67 & 60.9 \\
\hline Additional room & 12 & 22.6 & 8 & 14.0 & 20 & 18.2 \\
\hline $\begin{array}{l}\text { Repair \& } \\
\text { maintenance }\end{array}$ & 1 & 1.9 & 6 & 10.5 & 7 & 6.4 \\
\hline $\begin{array}{l}\text { Strengthening } \\
\text { roof \& wall }\end{array}$ & 5 & 9.4 & 1 & 1.8 & 6 & 5.5 \\
\hline House expansion & 1 & 1.9 & 1 & 1.8 & 2 & 1.8 \\
\hline Livestock & 2 & 3.8 & 0 & 0.0 & 2 & 1.8 \\
\hline $\begin{array}{l}\text { Finishing \& } \\
\text { flooring }\end{array}$ & 1 & 1.9 & 1 & 1.8 & 2 & 1.8 \\
\hline Others & 4 & 7.5 & 0 & 0.0 & 4 & 3.6 \\
\hline Total & 53 & 100.0 & 57 & 100.0 & 110 & 100.0 \\
\hline
\end{tabular}

Source: Field Survey 
Diverse housing priority found among poor households ranging from new construction to house space for livestock is crucial from supply of housing credit perspective. On the demand side, low or no demand for house for storage, home based work/enterprise, livestock etc. is mainly due to the fact that many of our respondents do not involve in such enterprises or not of that scale which require specific housing space. It is acute shortage of living space for family that drive most of the housing priorities and housing activities in the study areas across groups and regions.

Table 3. Housing Activity \& Purpose of Housing (Households).

\begin{tabular}{|c|c|c|c|c|c|c|c|}
\hline & & Karnataka & & Kerala & & Total & \\
\hline Activity & Purpose & No of HH & $\%$ & No of HH & $\%$ & No of HH & $\%$ \\
\hline \multirow[t]{2}{*}{ New construction } & immediate self use & 23 & 95.8 & 37 & 100.0 & 60 & 98.4 \\
\hline & Other (future use) & 1 & 4.2 & 0 & 0.0 & 1 & 1.6 \\
\hline \multirow{2}{*}{ Additional room } & immediate self use & 11 & 100.0 & 7 & 100.0 & 18 & 100.0 \\
\hline & Other & 0 & 0.0 & 0 & 0.0 & 0 & 0.0 \\
\hline Repair \& maintenance & immediate self use & 1 & 100.0 & 4 & 100.0 & 5 & 100.0 \\
\hline \multirow{2}{*}{ Strengthening roof \& wall } & immediate self use & 5 & 100.0 & 1 & 100.0 & 6 & 100.0 \\
\hline & Other & 0 & 0.0 & 0 & 0.0 & 0 & 0.0 \\
\hline \multirow{2}{*}{ House expansion } & immediate self use & 0 & 0.0 & 1 & 100.0 & 1 & 100.0 \\
\hline & Other (for business) & 1 & 100.0 & 0 & 0.0 & 1 & 100.0 \\
\hline \multirow{2}{*}{ Livestock } & immediate self use & 2 & 100.0 & 0 & & 2 & 100.0 \\
\hline & Other & 0 & 0.0 & 0 & 0.0 & 0 & 0.0 \\
\hline Finishing \& flooring & Other & 0 & 0.0 & 0 & 0.0 & 0 & 0.0 \\
\hline \multirow{2}{*}{ Others } & immediate self use & 4 & 100.0 & 0 & & 4 & 100.0 \\
\hline & Other & 0 & 0.0 & 0 & 0.0 & 0 & 0.0 \\
\hline All & & 49 & & 51 & & 100 & \\
\hline
\end{tabular}

Source: Field Survey

It may be noted that there is high demand for new house construction among lower income groups ${ }^{2}$ (see table-4). It substantiates the fact that low income households have high priority to new house construction over other housing activities than their counterparts in higher income groups. As high income households already have a house to meet basic requirement and they may have plan and priority for expansion, repair or renovation rather going for new house construction. On the other hand, many low income households do not have a structured and reparable house and their priority is mostly for new construction of house and at the earliest possible period so that they can move in. However, the trend is housing for self-use is foremost priority among household irrespective of income level but other housing activities goes with the level of income. Unless the basic housing need is not satiated, household priority for other housing activities or using house for income generating activities may not emerge irrespective of level of household income and scope for income generating activities. This is in contrast to what perceived by many housing credit lending institutions.

Level of household income is one of the key factors that influence housing priority and nature of housing activities. Overwhelming response for new house construction, particularly among the lower income group shows their desperate conditions. Many of them plan for a lower budget,

2 Lower income group does not refer to the income size group classification of the sample household purposefully made in this study. It refers to the low income poor household in general. smaller in size, low quality house at earliest possible period rather waiting for high budget bigger house. Our field observations and assessment show that low income households try to adjust with low budget low quality house to avoid rising cost and delay in completion. In this context, constraints in access to housing credit, particularly form formal sources might push them to go for low budget low quality houses unlike the wealthier and credit worthy households who can wait for good quality and high cost housing until have access to formal credit, finalize housing plan and other arrangement. Since the later group has an advantage of having livable house they may not show any hurry in housing matter. We will back on this point in subsequent sections.

On the other hand, poorer households would prioritize for low cost smaller size new house as early as possible rather waiting further because their dilapidated house fail to meet the housing need yet recurring high regular cost on maintenance and repair. This fact is substantiated by relatively higher proportion of new construction among lowest income size households than the high income size groups in both of the study regions (see table -4).

Surprisingly, low budget housing activities such as house for livestock, expansion of existing house, strengthening wall and roof etc. are very low or absent among lower income size households. There some region and group specific factors behind this trend. Arguably, house for livestock constitutes an important part of the total demand for housing in rural areas, but it found abysmally low in Karnatak and almost absent in Kerala. Livestock is a crucial household asset which 
supplements household income, but our data does not support its prominence mainly due to the increasing cost of livestock maintenance including arranging house, fodder and medicine etc. Acute shortage housing for family members and increasing cost of housing, outmigration and other factors discourage rural households to opt for housing for growing livestock. However, some household keep few livestock, not on regular basis or for market purpose that demand specific house space. As regard to type and nature of local housing activities, local environment and available housing materials ply a crucial role in determine the low cost housing demand. For instance, strengthening roof and wall, often believed major housing activities among low-income group, found very low in Kerala because of local housing requirement. It is necessary that the roof should be sloppy cement concrete to protect longer rain season unlike that in Karnataka where local made roof making materials called khapar are preferred. Housing technology using local materials for low cost housing found absent in both of the study areas shows lack of information and efforts. All these factor do influence housing priority and activities at local level.

Table 4. Housing Activities by Income Groups (Annual average income in Rs).

\begin{tabular}{|c|c|c|c|c|c|}
\hline Karnataka & $\begin{array}{l}<\text { Rs. } \\
12000\end{array}$ & $\begin{array}{l}\text { Rs. } \\
12000- \\
18000 \\
\end{array}$ & $\begin{array}{l}\text { Rs. } \\
\text { 18001- } \\
\mathbf{3 6 0 0 0} \\
\end{array}$ & $\begin{array}{l}>\text { Rs. } \\
\mathbf{3 6 0 0 0}\end{array}$ & Total \\
\hline new construction & 66.7 & 46.7 & 53.8 & 47.4 & 50.9 \\
\hline additional room & 33.3 & 33.3 & 7.7 & 21.1 & 22.6 \\
\hline repair \& maintenance & 0.0 & 0.0 & 7.7 & 0.0 & 1.9 \\
\hline $\begin{array}{l}\text { Strengthening roof \& } \\
\text { wall }\end{array}$ & 0.0 & 13.3 & 7.7 & 10.5 & 9.4 \\
\hline house expansion & 0.0 & 0.0 & 0.0 & 5.3 & 1.9 \\
\hline livestock & 0.0 & 6.7 & 7.7 & 0.0 & 3.8 \\
\hline others & 0.0 & 0.0 & 7.7 & 15.8 & 7.5 \\
\hline finishing \& flooring & 0.0 & 0.0 & 7.7 & 0.0 & 1.9 \\
\hline Total & 100.0 & 100.0 & 100.0 & 100.0 & 100.0 \\
\hline \multicolumn{6}{|l|}{ Kerala } \\
\hline new construction & 63.6 & 67.4 & 46.7 & 47.4 & 60.0 \\
\hline additional room & 15.2 & 20.9 & 20.0 & 21.1 & 19.1 \\
\hline repair \& maintenance & 15.2 & 2.3 & 6.7 & 0.0 & 6.4 \\
\hline $\begin{array}{l}\text { Strengthening roof \& } \\
\text { wall }\end{array}$ & 0.0 & 7.0 & 6.7 & 10.5 & 5.5 \\
\hline house expansion & 3.0 & 0.0 & 0.0 & 5.3 & 1.8 \\
\hline livestock & 0.0 & 2.3 & 6.7 & 0.0 & 1.8 \\
\hline others & 0.0 & 0.0 & 6.7 & 15.8 & 3.6 \\
\hline finishing \& flooring & 3.0 & 0.0 & 6.7 & 0.0 & 1.8 \\
\hline Total & 100.0 & 100.0 & 100.0 & 100.0 & 100.0 \\
\hline \multicolumn{6}{|l|}{ All } \\
\hline new construction & 63.6 & 67.4 & 46.7 & 47.4 & 60.0 \\
\hline additional room & 15.2 & 20.9 & 20.0 & 21.1 & 19.1 \\
\hline repair \& maintenance & 15.2 & 2.3 & 6.7 & 0.0 & 6.4 \\
\hline $\begin{array}{l}\text { Strengthening roof \& } \\
\text { wall }\end{array}$ & 0.0 & 7.0 & 6.7 & 10.5 & 5.5 \\
\hline house expansion & 3.0 & 0.0 & 0.0 & 5.3 & 1.8 \\
\hline livestock & 0.0 & 2.3 & 6.7 & 0.0 & 1.8 \\
\hline others & 0.0 & 0.0 & 6.7 & 15.8 & 3.6 \\
\hline finishing \& flooring & 3.0 & 0.0 & 6.7 & 0.0 & 1.8 \\
\hline Total & 100.0 & 100.0 & 100.0 & 100.0 & 100.0 \\
\hline
\end{tabular}

Source: Field Survey
In sum, housing demand and priority found in study areas show different dimensions of low segment housing sector, often ignored by the stakeholders by important from policy point of view. High preference for new house shows poor and non-repairable existing housing condition that underscores the quality, durability and incremental housing. It might prompted some households to opt for new house construction with a smaller budget rather investing on their dilapidated houses. Under rising income level, affordability and housing requirement the diverse housing priorities and activities emerge from the study areas may have impacts on housing finance market followed by

\section{Demand for Housing Finance and Microfinance for Housing in Study Areas}

Since both of the study areas experienced growth of micro credit over years and microfinance for housing (MFH) is also in operation, here we have attempted to assess the demand and supply of housing finance in general and $\mathrm{MFH}$ in particular. A broad estimate of housing finance in the study areas will provide basic understanding about potential of low segment housing finance market. Here, we have used

- Information collected from select community group members through interviews;

- Assessment of the physical housing, wherever possible, based on the materials used, cost of construction etc. and

- Interactions with the lending institutions.

Using household level data we measured the gap between demand and supply of housing credit, sources, other arrangements and its impact on housing among low income groups. Then we tried to focus on the role of MFH under the given MFH schemes to highlight role of MFH in terms of pushing housing activities among hitherto excluded low income groups from formal housing finance markets. Two specific aspect of MFH discussed here are understanding the quantity of $\mathrm{MFH}$ and $\mathrm{MFH}$ product design. Different indicators used to analyze and understand the potential of MFH in particular and overall low segment housing finance market in general are

- Average total demand for housing finance by region and income group and type of housing activities.

- Demand for different non-MFH credit (it includes credit from other formal sources, informal credit, and credit from $\mathrm{SHG} / \mathrm{NHG}$ )

- Pre and Post-MFH credit gap (difference between credit demanded and credit obtained)

- Demand for and use of micro-enterprise credit for housing activities (proportion of non-MFH micro-credit used for housing activities/expenditure)

- Changes in post-MFH housing expenditure (reduction in household expenditure on housing)

Information on housing credit demand in the study areas presented in the table -5 show that there is wide gap between demand and supply for housing credit among 
sample households, though the gap varies depending on the type and nature of housing needs, activities, availability of non-MFH credit and other factors. It appears that, MFH is inadequate to meet the housing credit demand in the study areas but it plays a crucial role in the low segment housing sector. However, being a part of the entire market MFH has reduced overall housing credit gap in both of the study areas substantially in Karnataka (67.7 to $32.4 \%$ ) and marginally in Kerala (95.3 to $78.4 \%$ ). Housing activity wise reduction in credit gap in additional house construction after MFH is remarkable in both of the areas but not in new construction of house, particularly in Kerala, which is the high priority among all households. It shows quantum of $\mathrm{MFH}$ is inadequate to address the housing credit and activities among the poor. MFH may be necessary but not sufficient for low segment housing sector. However, role of MFH goes beyond meeting the housing credit needs and our data support to substantiate it.

It may be noted that despite of low and inadequate average MFH available to the sample households, the demand for high fund required housing activities like new house construction remain very high and there was no remarkable increase in low fund required housing activities. So, the MFH product designed for the clients seems not matching to the most demanded activities but can cater to other housing activities like repairs and maintenance, expansion of existing house, strengthening roof and walls etc. where fund requirement is low and it may be within the amount of available MFH. This miss-match may be due to poor understanding about sector or overwhelming demand for new house construction, particularly among poorer households showing their priority for new houses but poor access and affordability to housing finance. As a result the credit gap between housing credit demand and credit obtained, though reduced after $\mathrm{MFH}$, but remain high which may push the poor and low income groups further in disadvantageous position.

However, MFH has played a crucial role in pushing housing activity among the rural groups who have been bypassed by the mortgage market. In fact, despite of a smaller amount and limited spread of MFH it works as kick start of pro-poor housing activities among house poor households. During our interactions with the respondents it emerged that starting a housing activities particularly new house construction is tough for the poor mainly because of arranging lump sum amount at initial stage of housing. But the quantum of MHF (fixed at maximum of 50,000/- per borrowers) actually induced housing activities among many respondents in the study areas. This is very important from several respects and from policy point of view.

We estimate the gap between demand and supply of housing credit and the share of MFH in it in study areas. MFH constitutes about one-fourth of total average housing credit demand of Rs 217081/- (see table - 5) which is much lower than usual mortgage housing finance markets. Though low segment housing finance market in rural areas suffer from potential risk of credit risks, irregular repayment, NPA and other factors but supply of MFH found well received in the both of the study areas with much lower loan amount. Households waiting long for housing activity, MFH works as a kick start to initiate housing plans and activities. It also prompted many low-income households to expedite their ongoing housing activities as well as related activities like fund arrangement, collection of housing materials and prepare for housing activities. Overall, MFH induces housing and other related activities which could not start before in rural areas.

Table 5. Gap in Demand \& Supply of Housing Credit in Study Areas.

\begin{tabular}{|c|c|c|c|c|c|c|c|c|c|}
\hline & \multicolumn{3}{|l|}{ Karnataka } & \multicolumn{3}{|l|}{ Kerala } & \multicolumn{3}{|l|}{ Total } \\
\hline & $\begin{array}{l}\text { New const } \\
\text { ruction }\end{array}$ & $\begin{array}{l}\text { Addit ional } \\
\text { room }\end{array}$ & Total & $\begin{array}{l}\text { New const } \\
\text { ruction }\end{array}$ & $\begin{array}{l}\text { Addit } \\
\text { ional room }\end{array}$ & Total & $\begin{array}{l}\text { New const } \\
\text { ruction }\end{array}$ & $\begin{array}{l}\text { Addit ional } \\
\text { room }\end{array}$ & Total \\
\hline $\begin{array}{l}\text { HH Involved in Housing Activity } \\
(\%)\end{array}$ & 51.9 & 23.1 & 100.0 & 72.2 & 14.8 & 100.0 & 62.3 & 18.9 & 100.0 \\
\hline $\begin{array}{l}\text { HH Credit Demanded for Housing } \\
\text { (Rs)/HH }\end{array}$ & 190185 & 80083 & 134000 & 211026 & 84688 & 297085 & 202500 & 81925 & 217081 \\
\hline Own-Fund before MFH (Rs./HH) & 69600 & 11818 & 40633 & 15513 & 17813 & 14028 & 36641 & 14342 & 26684 \\
\hline $\begin{array}{l}\text { Housing Credit Gap* before MFH } \\
\text { (Total credit demand - Self } \\
\text { arranged fund) Rs/HH }\end{array}$ & 120585 & 68265 & 93367 & 195513 & 66875 & 283057 & 165860 & 67583 & 190396 \\
\hline $\begin{array}{l}\text { Housing Credit Gap** after MFH } \\
\text { (Housing Cedit Gap before MFH - } \\
\text { MFH) }\end{array}$ & 70585 & 18265 & 43367 & 145513 & 16875 & 233057 & 115860 & 17583 & 140396 \\
\hline Pre-MFH Housing Credit Gap (\%) & 63.4 & 85.2 & 69.7 & 92.6 & 79.0 & 95.3 & 81.9 & 82.5 & 87.7 \\
\hline Post-MFH Housing Credit Gap (\%) & 37.1 & 22.8 & 32.4 & 69.0 & 19.9 & 78.4 & 57.2 & 21.5 & 64.7 \\
\hline
\end{tabular}

*Total credit demand - Self arranged fund) Rs/HH. **Total credit demand - Self arranged fund - MFH

Source: Field Survey

However, the post-MFH period was not very happy for those who could not arrange remaining fund for the entire housing activity, other than MFH. Household availed MFH found it harder to repay regularly along with microcredit loan. Under this this situation arranging for additional funds is challenging but some MFH borrowers tried hard to explore all possible sources including informal credit to complete their ongoing housing activity started initially with the amount of MFH. Those who failed to arrange the required fund experienced delay in completion of housing activity or 
could not complete at all. Some MFH borrowers used their critical saving, sold out ornaments, livestock, land or other assets, remittances in order to meet the housing credit gap. Repayment of housing loans was never been easier for low and irregular income groups. Under the given credit constraints (quantity, sources, timing, cost, repayment), $\mathrm{MFH}$ client may tend to compromise the quality, quantity and nature of housing activity.

It may be seen from the table- 6 that the average amount of own fund arranged for housing found higher (Rs 40633/-) in Karnataka compared to Kerala (Rs 14028/-) where the distribution of sample households was concentrate in bottom two categories of the income size groups. It indicates that households in higher income group use more own fund for housing activities unlike poorer groups. It may be noted that housing credit gap substantially reduced from 70 percent to 32 percent in Karnataka during post-MFH may be due to their relatively low budget housing activities against their counterparts in Kerala, where the gap reduced marginally from 95 percent to 78 percent. The differences in nature, pattern and type of housing activity considerably contribute to the credit gap but not adequately captured by the data. Higher demand for housing credit in Kerala was due to socioeconomic factors than a skewed distribution of sample households toward lower income size groups. Household strategy in arranging for remaining fund varies across groups in study areas. Another important trend is that with a smaller amount of housing credit borrowers were under pressure to complete their planned housing activity rather to delay it because of rising cost and urgency to shift to new house as early as possible in the absence of alternate housing arrangement. This is in contrast to the conventional argument of incremental housing among poor and low income groups who delay in their housing activity.

About alternate sources of housing credit the data presented in the table - 6 show that about 60 percent borrowers had to approach other sources for remaining fund depending on their housing activity, quantum of fund and other factors. Although this is a serious concern but also offers an opportunity for development of low segment housing finance market. Here complementary role of MFH in encouraging housing activity, arranging for remaining fund and expansion of market for housing finance is important from policy perspective. Varying demand for housing finance across groups and regions showing the dynamics of the market is partly evident from our data. The household responses showing diverse housing priorities, housing activities, fund arrangement etc. pre and post-MFH second the argument (see table - 6) and it implies some important aspect of housing finance market. High incidence of housing plan among sample households for new house construction in Kerala $(75 \%)$ prior to MFH shows inherent potential of rural housing finance market based on high level of income, more diversified occupation and nature of housing. But in Karnataka, households having low level of income, farming and other factors, only $42 \%$ households had plan for new house construction prior to availing $\mathrm{MFH}$, followed by $29 \%$ households planed for construction of additional room. Here socio-economic factors like household income, occupation, asset holding and access to housing credit remain crucial even after intervention of MFH. However, there is need to explore further about overall impact of MFH and household in long run and with other socio-economic factors that will reveal more about the housing finance market for low income groups.

Table 6. Housing Plan/Activity of Sample Households \& Impact of MFH.

\begin{tabular}{|c|c|c|c|c|c|c|}
\hline & \multicolumn{2}{|l|}{ Karnataka } & \multicolumn{2}{|l|}{ Kerala } & \multicolumn{2}{|l|}{ Total } \\
\hline & Nos of HH & $\%$ & Nos of HH & $\%$ & Nos of HH & $\%$ \\
\hline \multicolumn{7}{|l|}{ Housing Plan Prior to $\mathrm{MFH}^{*}$} \\
\hline New construction & 10 & 41.7 & 30 & 75.0 & 40 & 62.5 \\
\hline Additional room & 7 & 29.2 & 3 & 7.5 & 10 & 15.6 \\
\hline Repair \& maintenance & 0 & 0.0 & 4 & 10.0 & 4 & 6.3 \\
\hline Strengthening roof \& wall & 2 & 8.3 & 0 & 0.0 & 2 & 3.1 \\
\hline house expansion & 2 & 8.3 & 0 & 0.0 & 2 & 3.1 \\
\hline Finishing \& flooring & 2 & 8.3 & 0 & 0.0 & 2 & 3.1 \\
\hline Others & 1 & 4.2 & 3 & 7.5 & 4 & 6.3 \\
\hline Total & 24 & 100.0 & 40 & 100.0 & 64 & 100.0 \\
\hline All Sample Households & 53 & & 57 & & 110 & \\
\hline \multicolumn{7}{|c|}{ MFH has induced you to plan for your housing activity } \\
\hline Yes & 32 & 64.0 & 46 & 83.6 & 78 & 74.3 \\
\hline No & 18 & 36.0 & 9 & 16.4 & 27 & 25.7 \\
\hline Total & 50 & 100.0 & 55 & 100.0 & 105 & 100.0 \\
\hline All Sample Households & 53 & & 57 & & 110 & \\
\hline \multicolumn{7}{|c|}{ MFH has induced you to arrange for remaining amount } \\
\hline Yes & 27 & 60.0 & 28 & 87.5 & 55 & 71.4 \\
\hline No & 18 & 40.0 & 4 & 12.5 & 22 & 28.6 \\
\hline Total & 45 & 100.0 & 32 & 100.0 & 77 & 100.0 \\
\hline All Sample Households & 53 & & 57 & & 110 & \\
\hline
\end{tabular}

*Note: Only those households were considered who had any housing plan prior to MFH

Source: Field Survey 


\section{Supply of Housing Finance in Study Areas}

In general, supply of housing finance to low income groups has been grossly ignored by the formal financial institutions mainly because of lenders' risk perception about low income borrowers, lower profit margins, lack of land titles, and uncertainty of repossession. Since most of the sample households in our study are also client of microcredit supplied by MFI and banks their access to MFH was bit easier than non-microcredit borrowers. In both of the study areas credit lending institutions found follow careful scrutiny and put necessary conditions to avoid possible credit risks. Since, average loan amount of MFH is higher than usual micro-credit loans the lenders have become overcautious while selecting beneficiaries and sanctioning the loans. In this process many potential borrowers get excluded. However, the selection of beneficiaries, major terms and conditions and other loan process found more or less similar in both of the study areas except few variation in loan period, rate of interest and documentation.

As discussed earlier that average housing credit demand in Kerala found not only much higher than that of Karnataka but inter-income group there difference was lesser. In Kerala, a common and minimum housing requirements and standards followed that require a threshold amount of fund for housing activity irrespective of income size groups. It may be noted that the bottom most income size group had borrowed higher amount from other sources than average amount of MFH (Rs 61667) than their counterparts in higher income size groups. While demand for housing credit was diverse in Karnataka in terms of quantity it was fairly balanced in Kerala.

As regard to sources of non-MFH housing credit the conventional players like moneylender and relatives found dominant in both of the study areas. Though few household explored some banks and MFI for housing credit but it constitutes only marginal share in the total housing finance. Moneylender continues to meet the sizeable part of total housing credit needs. About one-fourth of sample households depend on moneylenders for housing credit in Kerala and for new house construction. Similarly, dependence on relatives found more or less similar in both of the study areas. Though borrowing from relatives is always reliable, cheaper and easy access than other informal sources the period loan period is usually shorter and immediate, especially in case of interest free credit.

Overall, a dismal performance of institutional finance in meeting low segment housing credit need is evident from the study. Though MFH played crucial role in inducing housing plan and activities but our data do not confirm that role of MFH in arresting overdependence on moneylender and other informal credit sources, particularly in Karnataka. In Kerala the traditional informal housing credit system seems still prominent may be due to better income and occupation pattern.

Table 7. Sources of Non-MFH Credit, Rate of Interest and Loan Period.

\begin{tabular}{|c|c|c|c|c|c|c|c|}
\hline & $\begin{array}{l}\text { Non-MFH Borrowing } \\
\text { HH (in Nos) }\end{array}$ & $\begin{array}{l}\text { Distribution of Non-MFH } \\
\text { Borrowing HH (\%) }\end{array}$ & $\begin{array}{l}\text { Non-MFH Borrowing } \\
\text { HH as \% total HH }\end{array}$ & $\begin{array}{l}\text { Non-MFH } \\
\text { Credit (Rs) } \\
\end{array}$ & $\begin{array}{l}\text { Rate of } \\
\text { Interest (\%) }\end{array}$ & $\begin{array}{l}\text { Loan period } \\
(\mathrm{yrs})\end{array}$ & $\begin{array}{l}\text { Outsta } \\
\text { nding (Rs) }\end{array}$ \\
\hline Karnataka & & & 53 & & & & \\
\hline Money lender & 12 & 41.4 & 22.6 & 91666.7 & 38.2 & 2.1 & 35444.4 \\
\hline Relative & 4 & 13.8 & 7.5 & 53750.0 & 24.0 & 3.3 & 45000.0 \\
\hline Bank & 3 & 10.3 & 5.7 & 38333.3 & 12.0 & & \\
\hline SHG & 7 & 24.1 & 13.2 & 34285.7 & 25.6 & 1.5 & 39000.0 \\
\hline Employer & 1 & 3.4 & 1.9 & 33000.0 & 24.0 & 14.0 & 26000.0 \\
\hline Other Source & 2 & 6.9 & 3.8 & 40000.0 & 22.0 & & \\
\hline Total & 29 & 100.0 & 54.7 & 61482.8 & 32.0 & 2.8 & 37833.3 \\
\hline Kerala & & & 57 & & & & \\
\hline Money lender & 20 & 45.5 & 35.1 & 104300.0 & 30.9 & 3.0 & 76470.6 \\
\hline Relative & 8 & 18.2 & 14.0 & 119375.0 & & & 33333.3 \\
\hline Bank & 6 & 13.6 & 10.5 & 103333.9 & 14.0 & 5.9 & 107491.8 \\
\hline Gold Mortgage & 1 & 2.3 & 1.8 & 50000.0 & & & \\
\hline Other Source & 9 & 20.5 & 15.8 & 120000.0 & 26.0 & & \\
\hline Total & 44 & 100.0 & 77.2 & 108886.4 & 26.7 & 5.0 & 76248.6 \\
\hline Total & & & 110 & & & & \\
\hline Money lender & 32 & 43.8 & 29.1 & 99562.5 & 33.7 & 2.3 & 62269.2 \\
\hline Relative & 12 & 16.4 & 10.9 & 97500.0 & 24.0 & 3.3 & 40000.0 \\
\hline Bank & 9 & 12.3 & 8.2 & 81667.1 & 14.0 & 5.9 & 107491.8 \\
\hline SHG & 7 & 9.6 & 6.4 & 34285.7 & 25.6 & 1.5 & 39000.0 \\
\hline Gold Mortgage & 1 & 1.4 & 0.9 & 50000.0 & 18.0 & & \\
\hline Employer & 1 & 1.4 & 0.9 & 33000.0 & 24.0 & 14.0 & 26000.0 \\
\hline Other Source & 11 & 15.1 & 10.0 & 105454.5 & 25.0 & & \\
\hline Total & 73 & 100.0 & 66.4 & 90054.8 & 29.1 & 3.5 & 59784.9 \\
\hline Std. Deviation & & & & 100388.1 & 14.1 & 3.0 & 60907.4 \\
\hline
\end{tabular}

Source: Field Survey 
Use of general microcredit loan for housing found prominent among MFH borrower as it is often argued that the group members use to channelize their micro-enterprise loan into housing activity. About 29 percent households in Kerala and 14 percent in Karnataka had used their group loan for housing activity. In fact, most of the housing group loan activities in Kerala outpace microenterprise loans. In Karnataka group loan used for housing found the second most important after agriculture. It implies that so long as housing credit needs are unmeet there is strong possibility of diversion of microenterprise loan into housing activities. Therefore, it is important for the lending institutions to consider the both housing and non-housing credit needs of their clients while designing financial products. Effort to balance between both types of products is urged for the financial institutions dealing with low segment financial products.

Table 8. Household Borrowing Pattern (Non-MFH) for Housing Activity.

\begin{tabular}{|c|c|c|c|c|c|c|}
\hline & Income Groups & Borrowing HH (\%) & $\begin{array}{l}\text { Amount } \\
\text { Borrowed (Rs) }\end{array}$ & $\begin{array}{l}\text { Rate of Interest } \\
(\%)\end{array}$ & $\begin{array}{l}\text { Loan Period } \\
\text { (Yrs) }\end{array}$ & Loan Outstanding (Rs) \\
\hline \multirow[t]{5}{*}{ Karnataka } & $<$ Rs. 12000 & 10 & 61667 & 42 & 2 & 24667 \\
\hline & Rs. $12000-18000$ & 31 & 38889 & 38 & 2 & 21667 \\
\hline & Rs. $18001-36000$ & 21 & 55000 & 30 & 3 & 61000 \\
\hline & $>$ Rs. 36000 & 38 & 83455 & 24 & 4 & 46600 \\
\hline & Total & 100 & 61483 & 32 & 3 & 37833 \\
\hline \multirow[t]{3}{*}{ Kerala } & $<$ Rs. 12000 & 44 & 97948 & 28 & 3 & 79273 \\
\hline & Rs. $12000-18000$ & 56 & 120000 & 26 & 7 & 77330 \\
\hline & Total & 100 & 110256 & 27 & 5 & 78259 \\
\hline \multirow[t]{5}{*}{ Total } & $<$ Rs. 12000 & 31 & 93000 & 30 & 3 & 67572 \\
\hline & Rs. $12000-18000$ & 46 & 97879 & 31 & 4 & 58776 \\
\hline & Rs. $18001-36000$ & 8 & 55000 & 30 & 3 & 61000 \\
\hline & $>$ Rs. 36000 & 15 & 83455 & 24 & 4 & 46600 \\
\hline & Total & 100 & 90611 & 29 & 4 & 60511 \\
\hline
\end{tabular}

Source: Field Survey

As regard to repayment of non-MFH, borrowers in Karnataka, particularly from the bottom income group performed better than their counterparts in Kerala. In fact, average outstanding of non-MFH in case of bottom most income group in Karnataka was Rs 24667 i.e. three times lower than their counter parts in Kerala (Rs 79273). It may be due to fact that the cost of credit was much higher in Karnataka where average interest rate was 42 percent, the highest among all categories, than 28 percent in Kerala. Repayment of MFH also gets affected by the serving to high non-MFH credit where cost of informal credit is high. Lower average cost of non-MFH and fairly longer loan term MFH in Kerala might influence high average outstanding. The differences in informal housing credit and it impact on borrowers in two different scenarios gives a broad ideas about segmented hosing finance market for the low income groups.

\section{Summary \& Conclusion}

From our analysis it appears that despite of some small quantity and other constraints the impacts of the MFH has been crucial in inducing pro-poor housing activities [11]. But it fail to meet the credit gap in low segment housing market. Given the diverse housing priorities and credit needs there is need for categorizing housing credit based on the demand, supply and the loan period across borrowers to serve them better. Impact of MFH on nature of housing activities found diverse across region and social groups. Inadequate quantity of MFH has induced some household to compromise with quality and smaller size units and complete it at one go rather opt for bigger size and quality housing units in progressing manner. This is in contrast to earlier studies that low segment housing is progressive in nature due to inadequate housing finance. Here both quantity and quality of MFH play crucial role in household decision making on housing, borrowing and resource use pattern. Our data support the trend that inadequate MFH in the absence of other institutional housing finance results in multiple informal borrowings, delay in completion, compromising with construction quality, depletion of assets, increasing default rate etc. It appears that the crucial link between housing, employment and income earning activities is missing in the designing of housing finance product including MFH. On the supply side, MFH constitutes only very low portion of total portfolios of the credit lending institutions like MFIs, banks, cooperatives etc. MFH has kick started pro-poor housing plan and activities and also induced them arranging for possible housing funds [10]. Hence, MFH has improved pro-poor housing activities but difficult to measure improved housing condition of the poor. It need further detail study.

Finding of the study may help credit lending institution to design and positioning their products effectively. Housing loans can be grouped into different product lines - small, medium and large instead of uniform MFH products. Efforts should be made to estimate the actual and potential demand of low segment housing market before allocating the portfolios for the same. Our analysis suggests the following:

- Low segment housing sector has huge market potential but not adequately explored by MFH and other credit lending institutions. 
- With rising in income MFH borrowers will demand diverse and more fund for new housing activities.

- MFH products design needs special attention to accommodate group and region specific aspects.

Based on our findings we offer some policy suggestions to make flexible repayment and second or top up loans depending upon client's need, type of housing activity plan, repaying capacity, source of earnings etc. Potential credit risk in the sector can be reduced by appropriate assessment of the borrowers and flexible loan term and conditions. Suitable partnership between credit lending institutions and other stakeholders may be encouraged for development of a vibrant low segment housing finance market.

\section{Annex-1}

Table - I: Distribution of Sample Households by Major Occupations.

\begin{tabular}{lllllll}
\hline Major & \multicolumn{2}{l}{ Karnataka } & Kerala & \multicolumn{3}{l}{ Total } \\
\cline { 2 - 7 } Occupation & No & \% & No & \% & No & \% \\
\hline Agriculture & 18 & 34 & 2 & 4 & 20 & 18 \\
$\begin{array}{l}\text { Livestock } \\
\text { Construction }\end{array}$ & 0 & 0 & 1 & 2 & 1 & 1 \\
worker & 1 & 2 & 1 & 2 & 2 & 2 \\
Regular & 2 & 4 & 6 & 11 & 8 & 7 \\
service & & 11 & 7 & 12 & 13 & 12 \\
Retail trading & 6 & 6 & 12 & 21 & 15 & 14 \\
Skilled laborer & 3 & 42 & 24 & 42 & 46 & 42 \\
Wage laborer & 22 & 2 & 4 & 7 & 5 & 5 \\
Other & 1 & 100 & 57 & 100 & 110 & 100 \\
Total & 53 & & & & & \\
\hline
\end{tabular}

Source: Field Survey

Table-II: Distribution of Household by Income (Annual) Size Groups.

\begin{tabular}{lllllll}
\hline \multirow{2}{*}{$\begin{array}{l}\text { Income Size } \\
\text { Groups }\end{array}$} & \multicolumn{2}{l}{ Karnataka } & \multicolumn{2}{l}{ Kerala } & \multicolumn{2}{l}{ Total } \\
\cline { 2 - 7 } & No & \% & No & \% & No & \% \\
\hline$<$ Rs. 12000 & 2 & 4 & 24 & 42 & 26 & 24 \\
Rs. 12000-18000 & 15 & 28 & 23 & 40 & 43 & 39 \\
Rs. 18001-36000 & 13 & 25 & 3 & 5 & 15 & 14 \\
$>$ Rs. 36000 & 23 & 43 & 7 & 12 & 25 & 23 \\
Total & 53 & 100 & 57 & 100 & 109 & 100 \\
\hline
\end{tabular}

Source: Field Survey

\section{Biography}

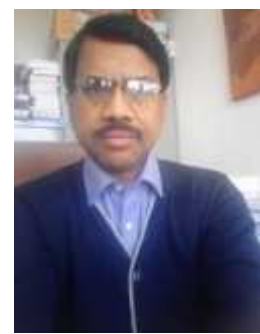

Basanta K Sahu is a faculty member in Economics Area, Indian Institute of Foreign Trade, Delhi India. He was visiting Chair Professor at Tel Aviv University (2012-13) and has worked at Indian Institute of Management, Sambalpur University; Institute of Economic Growth, and NABARD. His reseach covers household risk coping, water, drought, food insecurity, gender, microfinance, poverty and livelihood issues. He has more than 40 research publications and actively participated in several policy debates and analysis during last fifteen years. Recently he has been honored with 'Academician of Social Sciences' by IASS (USA) for contribution to the respective fields as well to wider society.

\section{References}

[1] Harvard Joint Center for Housing Development Studies, Graduate School of Design. (2000). Housing microfinance initiatives - synthesis and regional summary: Asia, Latin America and Sub-Saharan Africa with selected case studies.

[2] UN Habitat, (2011). Cities and Climate Change: Global Report on Human Settlements 2011, Washington, DC.

[3] Planning Commission (2007) Report of the 11th Five Year Focus on Slums, Govt. of India, Ministry of Housing and Urban Poverty Alleviation, New Delhi.

[4] National Urban Housing and Habitat Policy 2007 (NUHHP), Ministry of Housing and Urban Poverty Alleviation, Govt. of

[5] Ferguson, Bruce and Haider, Elinor (2000). "Mainstreaming Microfinance of Housing" Inter-American Development Bank.

[6] Asian Development Bank, (2007). Housing Finance II (HUDCO).

http://www.adb.org/Documents/Profiles/LOAN/30204013.ASP.

[7] Centre for Innovation in Shelter and Finance (2014) Housing Microfinance in Southern India: A Case Study from Growing Opportunity Finance and Habitat for Humanity India's Technical Assistance Centre Www.habitat.org/sites/default/files/cisf_go_india_case_study. pdf.

[8] Manoj P. K, (2009), "Emerging Technologies and Financing Models for Affordable Housing in India", Directorate of Public Relations and Publications, CUSAT, Kochi, Kerala, April 2009.

[9] IIM Ahmedabad (2000), "Impact of Investment in the Housing Sector on DGP and Employment in the Indian Economy", a study sponsored by HUDCO, Indian Institute of Management, Ahmedabad, July 2000.

[10] RBI, (2009). Committee on Financial Sector Assessment (CFSA), India's Financial Sector: an Assessment.

[11] Sahu B. K, (2010). 'Microfinance for Housing in India', CMR Report Series No - 6, CMR, BIRD, NABARD, Lucknow. Plan (2007-2012) Working Group on Urban Housing with India, New Delhi. 